\title{
The South African National War College military history staff ride as a deep learning experience
}

\author{
James Jacobs \& Johan Wassermann 306 \\ University of Pretoria
}

\begin{abstract}
In this article, based on a study rooted in interpretivism, the South African National War College military history staff ride, as an education and training method related to the curriculum of the senior staff programmes since 2002, is discussed. The education and training process, with specific reference to the staff ride to military battle sites and the associated application of the theory of operational art, were researched according to the tenets of the theory of deep learning. While using the historical-comparative method during the staff ride enabled the majority of the students to determine which viable options were available to the commander, not all students were necessarily able to relate deep learning to critical thinking. Consequently, in certain instances, surface learning tended to dominate simply because that was the educational world into which the students had been socialised. Furthermore, the facilitation process did not always fully serve the students by completely weaning them off learning habits associated with surface learning. Consequently, while being able to claim some deep learning successes using the staff ride, continuous reflection and educational interventions are needed to maintain the successes achieved and to use these as a building platform for deep learning during future staff rides.
\end{abstract}

Keywords: staff ride, deep learning, military history, South African National War College

\section{Introduction}

Over time, armed forces and their commanders constantly had to contemplate how best to prepare for military operations. One of the ways to do so was to turn to military history. More specifically, this was done by conducting a historical study, which became known as a 'staff ride' to fill the gap in operational preparation. A staff ride is a historical study of a military campaign or battle, which includes the following:

- a prior detailed study of related historical evidence;

- a field visit to the campaign or battle site to put the historical evidence studied into a geo-spatial context; and

- $\quad$ application of the lessons learnt about the military campaign or battle in a practical manner.

As such, it can be argued that the military history staff ride is a learning activity in which students analyse the actions of military commanders and their forces and use 
current military doctrine as a benchmark to understand and evaluate the aforementioned commanders as wartime leaders. ${ }^{307}$

In light of the above, this article deals with the military history staff ride as a deep learning experience. Universities in their role as institutions that conduct adult education, generally encourage students to think for themselves, to develop their own understanding of complex issues, and to make it a habit to think critically. In order to achieve personal understanding and to develop critical thinking abilities, deep learning is used as an approach at tertiary institutions accredited by to universities, such as staff colleges. Deep learning as an approach to the learning process relies on the intention for students to develop a critical mindset with the approach that the educator's knowledge is but an expression of current scientific research results, something that can change. This involves relating ideas and using evidence in ways determined by the tenets of a specific subject discipline. Deep learning stands in contrast to surface learning, with the latter generally involving actions aimed at reproducing learning material by means of rote learning. ${ }^{308}$

More specifically, this article focuses on the experiential value of the military history staff ride to the education and training of senior officers on the Joint Senior Command and Staff Programme (JSCSP) at the South African National War College (SANWC) of the South African National Defence Force (SANDF). Conducted since 2002, these staff rides, with their unique and persuasive nature of drawing on the past to learn in the present, focus on the operational level of war. They also serve to evaluate commanders of campaigns and major battles and stand in contrast to tactical staff rides, which focus mainly on the conduct of battles. ${ }^{309}$ The research aim of the study on which this article is based was therefore to understand, in an interpretivist manner, the JSCSP military history staff ride as a deep learning experience. In pursuing the stated research aim, our point of departure was that deep learning is the appropriate learning theory to understand how staff rides can contribute to critical thinking and the ability to solve work-based problems. The research question pursued was therefore: To what extent does the military history staff ride promote deep learning?

\section{Background and context}

The first recorded use of staff rides in military education and training was in the Prussian General Staff system of the nineteenth century. A select group of officers would annually accompany the Chief of Staff of the Prussian Army on a military exercise. During this exercise, they used fictitious military problems or examples from military history to develop the problem-solving abilities of the selected officers. Although military history was used in the discussions, the focus was on the use of terrain in border areas where they thought future wars might occur. In the process, the Prussian borders were divided into possible theatres of operations and discussions centred on possible military scenarios in these theatres and on solutions to possible military problems. On one level, the staff rides was therefore more like a tactical exercise without troops than the contemporary historical staff ride. On another level, the similarity of the Prussian Army exercises to the modern historical staff ride is that the Department of Military 
History of the Prussian General Staff provided lessons from past wars in the respective potential theatres of operations on the Prussian borders. It is also worth noting that the contemporary concept of a staff ride was derived from the fact that the Prussian officers who participated in the exercises, used horses to ride across potential battlefields. ${ }^{310}$

The British Army had a similar approach circa 1912. The British Army opted to use historical case studies on terrain that was similar to where wars had occurred. They did not travel to the actual campaign or battle sites as such. Case studies were selected where the military forces deployed were similar to those required for the contemporary staff ride. The actual positioning of the forces was then transferred to the locality where it was proposed that the exercise would be conducted. For example, campaigns and battles of the American Civil War of 1861-1865 were used to exercise officers in campaign and battle planning on terrain in Britain that was similar to that in the United States of America (USA), where the historic events actually occurred. ${ }^{311}$

After the First World War of 1914-1918, British officers visited European battlefields related to the conflict and American battlefields from the Civil War where the focus was on the study of tactical aspects of the campaigns and battles. This was, however, still very much a tactical exercise without troops. In the aftermath of the Second World War of 1939-1945, Allied wartime generals like Field Marshal BL Montgomery took British officers to Europe on battlefield tours to study tactics and teach them about the nature of war. In 1979, Montgomery's old age put an end to these tours, and staff colleges took over the duty of conducting staff rides. From 1997 onwards, the newly established Joint Services Command and Staff College in Britain continued with this practice. According to Hall, the battlefield tours became more rigorous and integrated with the Staff College curriculum. $^{312}$ The study material, which included historical evidence, focused on strategic and operational aspects and demanded a high level of critical thinking and, in doing so, leant more towards the concept of a staff ride than towards a battlefield tour.

The staff ride in its present format had its origin in the United States (US) army when, in 1906, the Assistant Commandant of the Army General Command and Staff College at Fort Leavenworth in Kansas took 12 student officers to the Civil War battlefields of Georgia. Until the 1930s, these staff rides played an important role in the curriculum of this college but due to a lack of personnel, this practice was abandoned during the Second World War and was forgotten for nearly two decades. In the late 1960s, Fort Leavenworth reintroduced the practice, and both the US Army War College in Carlisle, Pennsylvania and the US Army Military Academy at West Point followed suit. ${ }^{313}$

In the US armed forces, the practice of staff rides has been developed into a fine art, and several historical works, as companions to specific staff rides, have been published. Additionally, manuals on how to plan and conduct staff rides were published by the US Army Center of Military History. These could be adapted for other countries. ${ }^{314}$ Currently, US army officers go on staff rides wherever they are stationed in the world. In 1987, for example, they participated in over 300 staff rides, a number equal to those participated in annually by the British armed forces. This demonstrates the value of this practice as an educational and teaching activity. ${ }^{315}$ 
In other parts of the Global North, the Dutch and Irish armed forces also use historical staff rides in the education of their officers' formative training courses. In the cadet courses of both these countries, historical staff rides are used to enhance the classroom experience and allow cadets and officers to gain first-hand experience of specific battlefield conditions. ${ }^{316}$

Having considered the evolution and use of staff rides in the Global North, the focus now turns to South Africa as part of the Global South. With the reintroduction of military history as a subject in the curriculum of the Senior Command and Staff Duties Course at the South African Army College in 1998, the author developed a staff ride in the KwaZulu-Natal region. This education and training activity served the said course and the Military Health Service Staff Course until 2001. Subsequently, the arms of service courses were no longer presented as they fused into the JSCSP at the SANWC, from where the staff rides have since been conducted. Currently, the military history staff ride is part of the subject Military History. However, the staff ride also comprises the use of the theory of operational art, which refers to current SANDF doctrine on warfighting. The staff ride can therefore be seen as a combined interdisciplinary, practical application of two subjects on the JSCSP, namely Military History and Operational Art.

Until 2018, the JSCSP was an accredited qualification with the Safety and Security Sector Training Authority (SASSETA), and the subjects in the curriculum of the JSCSP were converted into unit standards to bring it in line with SASSETA requirements. The unit standard used for military history was US 119923, with the expected outcome being to equip officers to function at the operational level of war by developing their skills in evaluating the impact of the evolution of war on current military issues. A further outcome was to broaden their understanding of military single service, joint and multinational (combined) operations, the management of defence, and the wider aspects of conflict. ${ }^{317}$

By 2018, four different staff rides utilising the history of warfare in Southern Africa had been developed. To optimise the existing education and training opportunities, the same staff rides are not repeated year after year. In the process, the following staff rides were developed. In KwaZulu-Natal, the rise of the Zulu kingdom under King Shaka and his contribution to the evolution of war, 1818-1828, were studied. This was followed by a study of the Anglo-Zulu War of 1879, and the Anglo-Transvaal or First Anglo-Boer War of 1880-1881 in the Natal theatre of operations. Also studied was the Anglo-Boer War or South African War of 1899-1902. Related to this conflict, the operations of the invasion of Natal in 1899 by the Boer commandos and the British efforts to relieve the Siege of Ladysmith were studied.

A staff ride focusing on the Northern Cape, the eastern part of the Free State and Lesotho was also organised. In this staff ride, the rise of the Basuto under King Moshoeshoe and its contribution to the evolution of war was studied. A study of the Free State-Basuto Wars of 1858-1868 was followed by a study of the conduct of military operations in the Northern Cape during the South African War ending with the British occupation of Bloemfontein on 13 March 1900. 
Mpumalanga and Limpopo, two South African provinces, were also the focus of a staff ride. For this staff ride, the study emphasis was the role played by Paramount Chief Sekhukune II in the war of 1867-1877 against the South African Republic, also known as the Transvaal. This staff ride also engaged with military operations during the AngloTransvaal War of 1880-1881 in the Transvaal theatre of operations. The last campaign that was studied by the students on the JSCSP in this region was the Boer Commando retrograde operations from Pretoria to Komatipoort between July and August 1900 during the South African War.

The Eastern Cape and the region south of the Gariep or Orange River were also visited by a staff ride. The first campaigns studied on this staff ride considered the conduct of military operations during the Eighth War of Land Dispossession or Border War of 1850-1853 between the British colonial forces and the Xhosa forces. ${ }^{318}$ The operations and battles of the South African War during 1899-1900 in the area south of the Gariep River were also studied during this staff ride.

For logistical and historical reasons, the above-mentioned staff rides centred on selected regions. As can be gleaned from the above, a range of different conflicts between about 1820 and 1902 were included. This was done to expose the JSCSP to different military battle terrains, which called for different operations and different military history and historiographies and to ensure that the historical experiences and contributions of a wide spectrum of the South African population were represented. These staff rides also considered the manner in which modern armed forces use theatre space (opposing forces, terrain, infrastructure, weather, climate and population) in four different ways to develop the problem-solving abilities of their officers, namely

- $\quad$ tactical exercises, traditionally called manoeuvres, with troops;

- tactical exercises without troops, which utilise hypothetical war scenarios without forces, on maps and terrain;

- battlefield tours under the specialist guidance of a military historian to the terrain on which actual campaigns and battles are conducted; and

- $\quad$ historical staff rides, which is the focus of this article.

In the military staff rides outlined above, the students conducted a thorough prestudy of selected campaigns and operations to be visited that year by means of historical publications. They undertook extensive visits to the different operational and battle sites with the aim of integrating lessons learnt from the staff ride with current military problems; and. They further evaluated the actions of historic personalities in order to learn lessons for future warfare. ${ }^{319}$ This student-centred involvement was paramount and critical to ensure deep learning.

\section{Literature review and theoretical framing}

Deep learning, as opposed to surface learning, developed as an educational theory in the twentieth century. The intention of surface or rote learning is mainly to cope with course requirements in an uncritical manner. It is focused on reproducing knowledge on the premise that the educator conveys universal truths in class, which must be 
regurgitated as accurately as possible in tests and examinations. Therefore, the emphasis in this type of learning is routinely on memorising facts or carrying out set procedures. Such learning also adds little value or meaning to the course of study, especially for application in the workplace. ${ }^{320}$

Deep learning, on the other hand, aims to understand ideas. The student seeks to relate ideas to previous knowledge and experience, and looks for patterns and underlying principles when studying. In the context of deep learning, students further check evidence and relate it to conclusions, examining the logic of academic treaties and arguments cautiously and critically in order to become aware of their own understanding as it develops. With deep learning, students are expected to be actively involved and interested in course content, and they work towards applying their knowledge of such content in the workplace. ${ }^{321}$

In 1987, Entwistle, a leading deep-learning theorist, developed a heuristic model to demonstrate factors that would determine whether a student would adopt a deep or surface approach to learning. This model was adapted over time, and by 2009 , a more elaborate model emerged. According to the 2009 model, the main factors determining whether deep learning takes place are student characteristics and the features of the teaching-learning environment. ${ }^{322}$ Student characteristics, such as intelligence, motivation and motives, are important, but other factors, such as subject-specific knowledge and conceptions of knowledge and learning, are equally important in determining whether a deep learning approach is adopted.

The most decisive factor influencing the learning process is, however, how educational institutions approach the learning process. This starts with the beliefs about teaching and learning and the role of the the facilitator, which are then followed by the specific approach adopted in terms of facilitating a specific subject discipline. The end state of the learning process must also be clear. This, in turn, will determine the selection and organisation of course content. ${ }^{323}$ In theory, the aforementioned should be followed by the specific approach adopted for the facilitation of learning. Facilitators should provide an overview of the subject discipline, monitor its delivery and, at the same time, arouse the interest of the students, especially when linking the application of knowledge to the workplace. The facilitators should also facilitate learning in a way that encourages thinking and understanding and exemplify ways of thinking by emphasising the critical features of a specific subject area. In the context of deep learning, it is also important to focus on the specific ways of thinking and practising in a specific subject, such as Military History. ${ }^{324}$

For deep learning, the choice of facilitation methods is vital for the achievement of the above. In this regard, for example, lecturers cannot promote rote learning, as students are mere passive receivers of information. However, lecturing can be fruitfully used if combined with, for example, small group discussions, debates or simulations. Maximum participation of the student in the learning process is vital, and in this context, group discussions, problem-based learning and, most importantly, doing research, promote deep learning. ${ }^{325}$ To achieve the above, facilitators should support 
students mentally when they encounter complicated concepts in a subject discipline by moving from simple to more complex concepts by means of a spiral curriculum called scaffolded learning, which is also utilised in the assessment process to determine progress under formative assessment and summative assessment. The process of deep learning, however, is only completed when the facilitator has guided students to question the one-dimensional truthfulness of factual information. ${ }^{326}$

In the case of the staff rides, students not only have to analyse how historical commanders utilised contemporary military doctrine; they also have to determine the validity of such doctrine, based on historical case studies. From the point of view of historical science, the approach to a staff ride is based on Garraghan's argument that, although history never repeats itself in exactly the same format, a contemporary situation may resemble a situation in the past closely enough to be able to use past experience as a guide to the future handling of a similar situation. ${ }^{327}$ Staff rides also emphasise historical-comparative research with the focus on historical contingencies, a unique combination of particular factors or circumstances that may not be repeated when searching for a critical juncture to explain how several viable options may exist at a specific point in time. The researcher or student must also determine why a historical personality chose a specific course of action. ${ }^{328}$

In line with the educational practice of the US army in the twentieth century, the military history staff ride is regarded as an ideal education and training undertaking in exercising students to solve wartime problems by placing them in the positions of historic personalities and to analyse the different options available to these men as well as their final courses of action. It is also necessary to determine which influence this had on the ability of the historical commanders to reach the end state envisioned for wars, campaigns, major operations and battles. ${ }^{329}$ It is vital that the emphasis should not only be on training, but also on education, as the former is defined as a response to a predictable situation, while the latter focuses on critical thinking in the face of the unknown; thus, emphasising the unpredictability of war. ${ }^{330}$

According to Robertson, the ability to apply current military doctrine to a historic setting and enhance students' grasp of this through an evaluation of the practice of operational art by historic personalities, should be acquired by means of the staff ride..$^{331}$ At the SANWC, this means that application of the theory of operational art is based on current SANDF doctrine on warfighting with specific reference to planning and conducting military campaigns and major operations. This also means the exposure of students to the dynamics of war as they manifested in historical campaigns, major operations and battles, and leadership styles. Lastly, it needs to ensure that students are exposed to the impact of technology and terrain on the planning of campaigns, operations and battles.

\section{Research design and methodology}

This article was written with the research tradition of interpretivism in mind. Interpretivism holds that researchers should study and describe people's meaningful 
social actions. These actions, invariably subjective in nature, should be understood and not predicted. ${ }^{332}$ Within the epistemological position of interpretivism, the argument is that common sense guides people's daily lives. This is in stark contrast to the positivist tradition, which regards scientific knowledge as the only valid form of knowledge. Thus, interpretivists believe that, to understand human behaviour, one needs to comprehend what people regard as common sense. This is vital. Interpretivism also challenges the idea of objective knowledge and truth. Interpretivist researchers see facts as unsolidified and embedded in the meaning system. Facts are not objective and neutral; they depend on the context and people's interpretation. Therefore, interpretivists are not interested in generalising the results of their research. Consequently, the research methodologies used are sensitive to a specific context and cannot be generalised beyond that being studied. ${ }^{333}$ The current findings thus relate mainly to the use of academic studies in a specific staff programme (for example, the JSCSP) and are not necessarily applicable in other higher education study environments.

Ontologically speaking, it was realised that in this study, the reality was based on the existing approaches to the education of senior officers that should be changed if the need arose. This was in line with the interpretivist approach because, depending on circumstances, culture and experiences, people may not experience reality in a similar way. $^{334}$

Methodologically speaking, this research adopted a qualitative case study design, which searched for meaning and understanding and in which the researcher was the primary instrument of data collection and analysis. In a qualitative case study, an inductive investigative strategy is employed and the end product is richly descriptive. ${ }^{335}$ The research approach in this article was consequently based on qualitative methods with the related assumption that human beings construct associations as they engage with the phenomena they are interpreting. As a result, qualitative researchers, such as the authors of this article, tend to use open-ended questions so that the participants can share their views and experiences in an authentic manner. Qualitative researchers therefore strive to comprehend the background of the participants by visiting this context and gathering information personally. They also interpret what they discover, an understanding shaped by the researcher's own involvements and background. The basic generation of meaning is always social, residing in and arising from interaction with a human community - in the case of this study, those who went on the historical staff rides as part of the JSCSP. Furthermore, the process of qualitative research is largely inductive and the inquirer generates meaning from the data collected in the field. ${ }^{336}$

Within the above research design, the research methodology of this study involved examining a specific, bounded case study, namely to understand the extent to which deep learning was utilised in the staff ride as part of war studies subjects in the JSCSP, such as Military History and Operational Art. ${ }^{337}$ The purpose was thus to understand, by means of a qualitative case study, the students' approach to the staff ride since its inception at the SANWC in 2002, with specific reference to the programme of 2018. Consequently, the facilitation and assessment approach to the staff ride was analysed. To determine the ability to apply critical thinking in deep learning terms during the staff 
ride, a sample of 20 academic essays of 120 students on the programme of 2018 were analysed. This was done according to an assessment rubric that determined the extent to which each student used the theory of operational art to conduct a value judgement of a historical commander.

From an ethical point of view, during 2017, permission was gained from the Director: Counterintelligence of the SANDF for a study on the programme during 2018. The ethics committee of the Faculty of Education of the University of Pretoria subsequently approved a PhD study with the core focus on the programme of 2018 (clearance number HU 18/10/04). Consequently, the practical application of the above research aspects have been considered.

\section{Mapping the staff ride on the JSCSP}

Robertson emphasises the importance of a preliminary study to be conducted by students on the historical background of the area to be visited by the staff ride. ${ }^{338}$ If this is not done properly, the staff ride degenerates into a mere battlefield visit, where the facilitator does all the work and student involvement is virtually non-existent. Before the staff ride, the first author therefore presented lectures on the background to the different wars to the students. This served to orientate the students and help them in their preliminary literature study. Students received reading material on their respective topics related to the staff ride three weeks prior to the learning event and they were also tasked with conducting their own research on topics allocated to them for the staff ride.

During the staff ride itself, the corresponding author lectured the students on the sequence of events during each historical campaign or battle and they had the opportunity to ask critical questions. Two student syndicates were allocated per campaign, and they were given the duty of evaluating the application of operational art by the two opposing commanders, respectively. For example, one syndicate would evaluate a British commander while the other syndicate would evaluate the opposing Boer commander during, for example, the Transvaal operations during the Anglo-Transvaal War of 18001881. During the staff ride, every day started with a lecture providing an overview of the campaign to be studied. This was done in adherence to the first step in Entwistle's model of deep learning by providing an overview and monitoring educational delivery. ${ }^{339}$

The next step was the visit to sites, such as the location of headquarters and logistic bases, as well as to the different battlefields. The author or guest speakers briefly illustrated the sequence of events to the JSCSP students. Thereafter students had the opportunity to walk the battlefield and, where possible, visit museums. In terms of deep learning, the process was designed to arouse student interest in real-life historical contexts and to explain the components of the campaign under study. ${ }^{340}$ Although lectures - supported by PowerPoint presentations - were conducted every morning before the students visited the actual terrain, the facilitation was aimed at encouraging thinking and understanding by means of the debriefing at the end of each day. One could ask the question, why not let the students do the presentations? The reason for the facilitation was twofold. This was the first time that most of the JSCSP students 
had seen the actual terrain in the theatre of operations or set foot on the battlefields. It would thus be unfair to expect them to arrive and immediately conduct a presentation. The second reason was that their focus had to be on the application of the theory of operational art and not on the reconstruction of the chronology of events.

At the end of each day after arriving at their accommodation, the two student syndicates had to analyse the two opposing commanders for that specific campaign. Each syndicate then conducted a concise presentation on the sequence of events during the campaign to the student body as a whole. They also had to indicate how these events influenced the commanders' original campaign conceptualisations. The focus throughout was on the application of operational art. After working hours, the students had the opportunity to continue with their own research and the reading of the literature.

The last three staff ride steps, namely briefing, visits and presentations represent what Robertson classifies as a field study. ${ }^{341}$ After their return to the SANWC in Pretoria, the students carried out two steps. First, student presentations for formative assessment in each syndicate took place. The syndicates presented their evaluation of the respective historic personalities as campaign commanders to all the members of the directing staff and other students. The corresponding author facilitated the process and provided feedback on possible improvements. The second step was the submission of the research papers by individual students in the form of academic essays for summative assessment. As explained earlier, these essays were the units of analysis for this article.

Both the syndicate presentations and academic essays were assessed with the same assessment rubric. This was done to ensure continuity as related to deep learning. The rubric was also designed to provide students with a framework to analyse the application of operational art during a specific campaign. The point of departure of the rubric was the strategic situation and the aims of the belligerents, which led to the analysis of the formulation of the military strategic problem facing the commander. The focus was on guiding the student on 'how' to think and not 'what' to think in terms of their approach to the analysis of the campaign. However, it was important that the student had to determine whether the plans and actions of the campaign commander contributed to the solution of the problem on the strategic level. There were no right or wrong answers and it was the student's choice which part of the theory of operational art would be used to evaluate the actions of the historic military commander under discussion. The focus was on group discussions, debates and presentations as the first step to exchanging ideas. In the summative academic essay, students could further develop their own ideas on how to evaluate the campaign commander as a practitioner of operational art. This relates to Entwistle's guidelines of exemplifying ways of thinking, emphasising critical features and encouraging discussion. ${ }^{342}$ The process was finalised when the students received their assignments back and the directing staff provided feedback. The marks were then recorded. With that, the staff ride was completed.

\section{Analysing the academic essays for evidence of deep learning during the staff ride}

Until 2014 when he retired, the corresponding author assessed all the academic essays related to the staff ride of the JSCSP. In 2018, working as a consultant facilitator, 
he assessed an essay per syndicate, eight in total. In a work session with the directing staff, he discussed each product with them in order to guide them in the assessment process. As a result, this aspect of the assessment process promoted deep learning, as the process was a means to ensure consistency in grading the essay assignments. This was part of a system used at the SANWC called 'proof marking' where the assessors discussed how marks would be allocated to one product so that all the assessors applied the rubrics consistently during marking within a common framework. Proof marking - and the variation applied since 2018 - cannot be measured in absolute terms of consistency; rather, it promotes a relative common approach to assessment.

For the academic essay, i.e. the summative assessment of the staff ride, the students were assessed individually, and the assessment rubric was used to measure their level of ability to use the theory of operational art to evaluate the contribution of a historical commander to the evolution of war. The practical application of official doctrine in this manner is also related to training, but the development of critical thinking was situated within the ambit of education. The underpinning idea was that doctrine should never become dogma. Therefore, the final step that the student had to achieve was to use the case study to validate the doctrine.

With his experience in having assessed the group presentations and individual academic essays since 2002, the corresponding author concluded that, initially, only a small group of students succeeded in using the academic knowledge they had gained during the facilitation of the academic subjects, such as Military History, to understand military planning in the historical scenario in a deep learning manner. At first, the majority of students tended to provide merely a chronology of events without measuring the planning and management of the campaign by the historical commander according to the theory of operational art. This gradually improved due to the approach in facilitating the staff ride and guiding students, so that by 2018, the majority did apply the theory. ${ }^{343}$ This constituted a major breakthrough. However, before 2018 and also thereafter, only one student did more than just apply the theory to the case study. The student also critically analysed the validity of the theory of operational art based on the assigned case study. ${ }^{344}$

A problem that has persisted since 2002, and which appeared again during 2018, was the inability of certain students to conduct an argument in their academic essays through to its logical conclusion. ${ }^{345}$ For example, one of the concepts of the theory of operational art is the scope of the theatre of operations. This relates to opposing forces relating to each other in terms of time, space, resources and purpose. The terms 'deep', 'close' and 'rear' are used to describe how the operations of the opposing forces relate to each other. The 'close area' is where the combatants meet in battle. The enemy's 'rear area' (logistic installations, headquarters and communication centres) refers to the own forces' 'deep area' (where own forces conduct operations behind enemy lines). The idea is to analyse how the opposing commanders utilised this in planning and conducting the campaign strategy. ${ }^{346}$ Some students identified the close, deep and rear areas with illustrated maps, but did not explain how the opposing commanders utilised these concepts in the operation about which they were writing. ${ }^{347}$ In reality, the lack of 
depth of analysis should not be the problem as the staff ride is a good example of the integration of cognitive and social constructivist views as these relate to deep learning. The premise of constructivism is that knowledge is gained and expanded through active construction and reconstruction of theory and practice as per deep learning. ${ }^{348}$

With reference to the above, the staff ride is designed to contribute to the ability of students to apply insight they have gained into the nature of command in war during campaign planning. This is done according to an inductive reasoning process of using historical evidence and arriving at deductions and conclusions in order to design and manage a campaign plan. It is also an effort to demonstrate practically the complex nature of war. Furthermore, the staff ride provides the opportunity to apply critical thinking in a deep learning sense to a historical case study. Some students remarked that the process of evaluating the planning and conduct of campaigns by historical commanders assisted them during the campaign planning process, that is, their final assessment during the JSCSP in which they were provided with a fictitious scenario and had to design a campaign plan. It seems that, for these students, the analysis of how a historic campaign commander utilised the theory of operational art provided a useful framework of critical thinking when they had to design their own plans in a fictitious scenario. However, this was not necessarily true for all students.

The staff ride, as explained previously, was an ideal opportunity to augment the more theoretical learning process by allowing students to participate in an exercise simulating a real-life situation by studying an actual historical campaign. It was also a scenario that provided them with a problem to solve. The exercise therefore promoted deep learning in that the corresponding author (as facilitator), kept in mind the unique concepts on which the academic subject is built, and guided the students in understanding concepts leading to a better comprehension of the nature of war. ${ }^{349}$

The next question in terms of deep learning that needed to be considered was whether the assessment focused only on the range of knowledge, skills and understanding of subject content or whether it also considered that variations and creativity could lead to different solutions to problems as studied during the staff ride. The use of case studies focused on the analysis of the options available to commanders in history and an evaluation of the choices made. That in itself takes into consideration that there is more than one solution to a problem. Understanding why a military commander preferred a specific option for his plan develops critical thinking by developing the mind of a senior officer in finding solutions to military problems. ${ }^{350}$

\section{Conclusion}

Jessup and Coakley claim that the study of military history contributes to the development of officers to sharpen judgement, improve perception and broaden perspectives. ${ }^{351}$ In assessing how the staff ride differed from conducting the learning activity in a classroom situation, we found that lectures were still used, but were augmented with group discussions and debates, and therefore promoted deep learning. 
The staff ride described above contributed to the critical analysis of the conduct of historical commanders, using the theory on operational art as its measurement. In that way, critical thinking in a deep learning context was promoted, and laid the foundation for the student to find unique solutions to real-life problems in a war situation. The process of somatic learning enhanced the contribution of the staff ride to the adult education process on the JSCSP, as seeing the actual terrain and other artefacts of war provided a good opportunity to visualise the reality of past wars.

The staff ride as learning process represents a major leap in learning in contrast to the traditional method of learning by sitting in classrooms and listening for hours to endless lectures. Nazareth claims that insight into the nature of war can only come about by developing the imaginative powers of students. ${ }^{352}$ To that end, the staff ride contributed substantially. The extra funding needed to conduct this learning activity is therefore worth its while. The staff ride also has the advantage of demonstrating the validity of current SANDF doctrine in the theory of operational art as explained in the examples. One should, however, remember that doctrine is not dogma and that the validity of doctrine in a specific case study must be understood within the context of the events as they unfolded. The main advantage of the staff rides in testing the validity of doctrine is that it demonstrates that staff rides can work, not only in specific circumstances, but also when a commander must use his or her judgement to determine when to deviate from it.

Using the historical-comparative method enabled the student to determine which viable options were available to the commander, why he or she had chosen a specific course of action and whether this strengthened the validity of doctrine. One should keep in mind that doctrine is based on historical-comparative research. It is also a first step in the development of option formulation, a key aspect of the theory of the campaign-planning process later in the programme where commanders have to develop a campaign concept for their planning staff, outlining different options for the conduct of the campaign. ${ }^{353}$

It is clear that, by 2018 , the majority of students succeeded in analysing the actions of historical military commanders according to the theory of operational art. However, not all students were necessarily equal to the task of how it related to deep learning with reference to critical thinking and the ability to solve work-based problems. The result was that, in certain instances, surface learning tended to dominate, simply because that was the educational world into which the students had been socialised and which had shaped their views on education. At the same time, the facilitation process did not fully serve to wean them completely off their rote-learning habits associated with surface learning. Consequently, the development of critical thinking in a deep learning manner on the staff ride needs more emphasis. The essence of deep learning is to question continuously the truthfulness of existing knowledge. Theories are based on existing knowledge and their validity should constantly be questioned, otherwise the staff ride only strengthens the belief in current military doctrine and does not lead to the final step in critical analysis, namely the questioning of current knowledge by means of a specific theory. 


\section{ENDNOTES}

${ }^{306} \mathrm{Col}$ (Dr) Rtd CJ Jacobs, the corresponding author, served as the senior researcher and resident military historian at the South African National War College from 2005 to 2014, after which he retired from the South African National Defence Force (SANDF). Prof JM Wassermann is the head of the Department of Humanities Education in the Faculty of Education of the University of Pretoria. His research work focuses on both history and history education. This article is based on a PhD thesis, "Deep learning during the South African National Defence Force's Joint Senior Command and Staff Programme", which Dr Jacobs completed under the supervision of Prof Wassermann.

${ }^{307}$ WG Robertson. The staff ride. Washington, DC: US Army Center of Military History, 1987, 1.

${ }^{308} \mathrm{~N}$ Entwistle. Teaching for understanding at university: Deep approaches and distinctive ways of thinking. New York, NY: Macmillan, 2009, 1, 41.

${ }^{309}$ Curriculum Joint Senior Command and Staff Programme (JSCSP). Pretoria: SANDF, 2001.

${ }^{310} \mathrm{M}$ van Creveld. Command in war. London: Harvard University Press, 1985, 110; TN Dupuy. A genius for war: The German Army and general staff, 1807-1945. Fairfax: Lume Books, 1989, 49, 65.

${ }^{311}$ RCB Haking. Staff rides and regimental tours. London: Palala Press, 1912, 147-148.

${ }^{312}$ RGI Haycock. "The relevance and role of the battlefield tour and the staff ride for armed forces in the 21 st century introduction". Defence Studies 5/1. 2005. 5-14.

${ }^{313}$ WA Stofft. "The staff ride and civil war battlefields". 2004. <File://A $\backslash$ Reader's CompanionThe/Staff/Ride/and/Civil", 1, Accessed on 15.3.2021.

${ }^{314}$ Combat Studies Institute. "The staff ride: A guide to planning and conducting unit-level staff

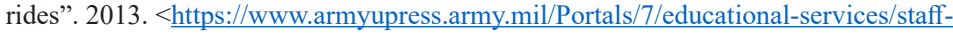
rides/the-staff-ride-overview-2-august-2013.pdf $>$ Accessed on 15.3.2021.

${ }^{315}$ Stofft op. cit.

${ }^{316}$ T Brinkel, D Murphy \& J Noll. "The staff ride as reflective practicum: Impressions and experiences of the Faculty of Military Sciences and Maynooth University". In W Klinkert et al. (eds), NL ARMS Netherlands annual review of military studies. The Hague: TMC Asser Press, 2019, 247-260.

${ }^{317}$ DJ van Oudtshoorn. JSCSP, Joint Warfare Assessment Plan. Pretoria: SANDF, 2018.

${ }^{318}$ Wars in South Africa go by different names, depending on, among other things, perspective and the changing historiographical positions adopted. The names used in this article refer to the names currently in use.

${ }^{319}$ Robertson op. cit., p. 5.

${ }^{320}$ Entwistle op. cit., p. 36.

${ }^{321}$ Ibid.

322 bid., p. 115.

${ }^{323}$ Ibid.

${ }^{324}$ Ibid.

${ }^{325}$ Ibid.

${ }^{326}$ S Ohlsson. Deep learning: How the mind overrides experience. Cambridge: Cambridge University Press, 2011, 1.

${ }^{327}$ GJ Garraghan. A guide to historical method. New York, NY: Fordham University Press, 1957, 14.

${ }^{328}$ WL Neuman. Social research methods: Qualitative and quantitative approaches. Essex: Allyn \& Bacon, 2000, 498.

${ }^{329}$ Robertson op. cit., p. 5.

${ }^{330}$ Haycock op. cit., pp. 5-14. 
${ }^{331}$ Robertson op. cit., pp. 5-6.

${ }^{332}$ F du Plooy-Cilliers, C Davis \& R Bezuidenhout (eds.). Research matters. Cape Town: Juta, 2014, 28.

${ }^{333}$ Ibid., p. 29.

${ }^{334}$ Ibid.

${ }^{335}$ SB Merriam \& EJ Tisdell. Qualitative research: A guide to design and implementation. New York, NY: Jossey-Bass, 2015, 37.

${ }^{336}$ JW Cresswell \& JD Creswell. Research design: Qualitative, quantitative and mixed methods approaches. London: Sage, 2017, 8-9.

${ }^{337}$ Merriam \& Tisdell op. cit., pp. 48-49.

${ }^{338}$ Robertson op. cit., pp. 11-12.

${ }^{339}$ Entwistle op. cit., p. 115.

${ }^{340}$ Ibid.

${ }^{341}$ Robertson op. cit., pp. 11-12.

${ }^{342}$ Entwistle op. cit., p. 115.

${ }^{343}$ Student identity protected, academic essay 1, 2018.

${ }^{344}$ Student identity protected, academic essay 4, 2018.

${ }^{345}$ Student identity protected, academic essay 1, 2018.

${ }^{346}$ L Olivier. JWP 101: Operational Art. Pretoria, 2006, Chapter 5, p. 3.

${ }^{347}$ Student identity protected, academic essays 3 \& 4, 2018.

${ }^{348} \mathrm{R}$ Killen. Teaching strategies for outcomes-based education. Lansdowne: Juta, 2000, xvii.

${ }^{349}$ Entwistle 115.

${ }^{350}$ DJ van Oudtshoorn. JSCSP, Joint Warfare Assessment Plan. Pretoria: SANDF, 2018, 6.

${ }^{351}$ JE Jessup \& RW Coakley. A guide to the study and use of military history. Washington, DC: Center of Military History, 2004, 31.

352 J Nazareth. Dynamic thinking for effective military command. New Delhi: Tata McGraw-Hill, $1976,83$.

353 JD Malan. The commander's appreciation at the operational level of war. Pretoria: SANDF, iv. 